\title{
PENERAPAN MACAM DAN DOSIS PUPUK ORGANIK TERHADAP PERTUMBUHAN DAN HASIL TANAMAN GANDUM (Triticum aestivum L.)
}

\author{
Prasetyo Ari Bow o ${ }^{1 *}$ Sumarmi $^{1}$, Sri Hardiatmi ${ }^{1}$ \\ Program Studi Agroteknologi, Fakultas Pertanian, Universitas Slamet Riyadi \\ Jl. Sumpah Pemuda No.18, Kadipiro, Surakarta, Jawa Tengah \\ $1^{*}$ \\ antoninugroho9@gmail.com
}

\begin{abstract}
ABSTRAK
Penelitian tentang "Penerapan macam dan dosis pupuk organik terhadap pertumbuhan dan hasil tanaman Gandum (Triticum aestivum L.)" telah dilaksanakan tanggal 08 November 2018 sampai 31 januari 2019 di Green House Fakultas Pertanian Universitas Slamet Riyadi Surakarta. Penelitian ini bertujuan untuk mengetahui dan menentukan pengaruh terbaik terhadap pertumbuhan dan hasil tanaman gandum. Rancangan penelitian yang digunakan adalah rancangan acak lengkap yang terdiri dari 7 perlakuan dan 5 ulangan. Perlakuan : 1) MD0 = tanpa pupk (kontrol), 2) MD1= pupuk kandang dosis $200 \mathrm{~g} /$ polybag, 3) MD2 = pupuk kandang dosis $400 \mathrm{~g} /$ polybag , 4) $\mathrm{MD} 3$ = pupuk guano dosis $200 \mathrm{~g} /$ polybag, 5) MD4 = pupuk guano dosis 400 g/polybag, 6) $\mathrm{MD} 5=$ pupuk kascing dosis $200 \mathrm{~g} /$ polybag, 7) MD6 = pupuk kascing dosis $400 \mathrm{~g} /$ polybag. Hasil penelitian menunjukkan bahwa : 1) penerapan macam dan dosis pupuk organik berpengaruh terhadap tinggi tanaman, jumlah daun, dan jumlah anakan, 2) penerapan macam dan dosis pupuk organik tidak berpengaruh terhada ap berat segar brangkasan, berat kering brangkasan, jumlah biji, berat biji, dan berat 100 biji, 3) macam dan dosis pupuk terbaik adalah MD2 (pupuk kandang dosis $400 \mathrm{~g} /$ polybag) karena dapat meningkatkan jumlah daun dan jumlah anakan.
\end{abstract}

Kata kunci : pupuk organik, pertumbuhan dan hasil tanaman gandum.

\section{ABSTRACT}

Research on "application of kinds and dosage of organics fertilizers to the growth and yield of Wheat plants (Triticum aestivum L.) " has been carried out from November 8, 2018 to January 31, 2019 at the Green house of the Agriculture Faculty, Slamet Riyadi University, Surakarta. This study aims : to knowing and determine the best influence on the growth and yield of wheat crops. The metode of this research was experimental designed by completely randomized design (CRD) consisting of 7 treatment and 5 replications. Treatment: 1) $M D 0=$ no fertilizer (control), 2) MD1 = manure dose $200 \mathrm{~g} /$ polybag, 3) $M D 2=$ manure dose $400 \mathrm{~g} /$ polybag, 4) MD3 = guano fertilizer dose $200 \mathrm{~g} /$ polybag, 5) MD4 = guano fertilizer dose $400 \mathrm{~g}$ / polybag, 6) MD5 = fertilizer vermicompost dose of $200 \mathrm{~g} /$ polybag, 7) MD6 = fertilizer vermicompost dose of $400 \mathrm{~g} /$ polybag. The results showed that: 1) the application of the type and dosage of organic fertilizer had an effect on plant height, number of leaves, and number of tillers, 2) the application of the type and dosage of organic fertilizer had no effect on fresh stover weight, stover dry weight, number of seeds, weight seeds, and the weight of 100 seeds, 3) the type and dosage of the best fertilizer is MD2 (manure dose of $400 \mathrm{~g} /$ polybag) because it can increase the number of leaves and the number of tillers.

Keywords: organic fertilizer, growth and yield of wheat crops. 


\section{PENDAHULUAN}

$\begin{array}{rrr}\text { Ketersediaan } & \text { pangan merupakan } \\ \text { masalah serius } & \text { yang terus }\end{array}$ diperbincangkan, baik pada tataran daerah, nasional, regional maupun global. Hal ini berkaitan dengan kejadian rawan pangan yang terjadi di berbagai belahan bumi. Kejadian rawan pangan secara global disebabkan oleh ketidakseimbangan antara ketersediaan dan permintaan pangan yang merupakan implikasi langsung dari ketidakseimbangan peningkatan jumlah penduduk dan peningkatan produktivitas pertanian.

Berdasarkan fakta tersebut, kiranya dibutuhkan bahan pangan alternatif yang dapat mensubtitusi bahan pangan pokok padi. Gandum merupakan salah satu komoditi pangan alternatif, dan dapat didiversifikasi menjadi pelengkap pangan pokok padi di Indonesia. Diversifikasi pangan yang paling berhasil adalah tepung gandum/terigu karena penggunaannya cukup luas dengan berbagai kemasan, siap saji dan praktis, akan tetapi selama ini kebutuhan industri gandum Indonesia dipasok dari gandum impor dan mengalami peningkatan dari tahun ke tahun (Anonim,2011).

Tanaman gandum beradaptasi secara luas dilahan kering pada kawasan 30$60^{\circ}$ LU dan $27-40^{\circ}$ LS. Tanaman gandum tumbuh dan berproduksi dengan baik, memerlukan suhu udara optimal $4-25^{\circ} \mathrm{C}$, dengan panjang penyinaran (fotoperiode) 9 13 jam per hari. Kondisi yang mirip dengan iklim subtropika mendukung pertumbuhan tanaman gandum (Nur, 2012). Pemilihan kondisi iklim yang tepat menentukan kandungan gluten gandum yang merupakan salah satu penentu utama kualitas gandum.

Aspek tanah yang digunakan sebagai media tanam pada budidaya gandum dapat mempengaruhi pertumbuhan dan perkembangan gandum. Dalam media tanam yang digunakan terdapat pupuk yang telah dicampurkan untuk mendorong pertumbuhan dan perkembangan tanaman gandum. Pemupukan organik pada tanaman gandum dapat meningkatkan kesuburan tanah sehingga dapat meningkatkan pertumbuhan dan hasil tanaman gandum. Permasalahannya adalah terdapat banyak macam pupuk organik yang kandungan unsur haranya berbeda- beda sehingga akan mempengaruhi pertumbuhan dan hasil gandum.

Selain masalah macam pupuk organik, penerapan pupuk dengan dosis yang tidak tepat juga dapat menjadi masalah karena penerapan dengan dosis rendah maka pengaruhnya tidak akan nampak: sedangkan penerapan dengan dosis tinggi maka akan menjadi tidak efisien karena pengaruhnya juga nampak.

Berdasarkan paparan tersebut di atas, peneliti bermaksud mengadakan penelitian tentang penerapan macam dan dosis pupuk organik terhadap pertumbuhan dan hasil tanaman gandum (Triticum aestivum L.), dengan tujuan untuk mengetahui dan menentukan pengaruh terbaik terhadap pertumbuhan dan hasil tanaman gandum.

\section{BAHAN DAN METODE}

Penelitian lapangan mulai dari tanam sampai panen dilaksanakan pada tanggal 8 November 2018 sampai 31 Januari 2019, bertempat di Green house Fakultas Pertanian Universitas Slamet Riyadi, Surakarta, dengan ketinggian tempat $80-$ $130 \mathrm{~m}$ di atas permukaan laut

Bahan yang digunakan dalam penelitian ini, antara lain : benih gandum varietas G10 (O/HP-82-A-15-1-4) diperoleh dari FP UKSW Salatiga, pupuk kandang padat dibeli dari toko pertanian Klaten, pupuk kascing dibeli di Mojodoyong, Kedawung, Sragen, pupuk guano dibeli dari Gua Gajah, Petakan, Ciawi, Karangnunggal, Tasikmalaya, tanah regosol kelabu didapat dari sawah desa Trucuk, Klaten, dan pupuk NPK Mutiara dibeli dari toko pupuk di Trucuk, Klaten, Sedangkan alat yang digunakan antara lain: polybag berukuran $30 \times 45 \mathrm{~cm}$, cangkul, meteran, gunting, alat tulis, ember, sprayer, timbangan, oven, label, dan papan nama.

Penelitin ini menggunakan rancangan dasar Rancangan Acak Lengkap (RAL) yang terdiri dari 1 faktor perlakuan dengan 7 taraf dan diulang 5 kali Adapun perlakuannya adalah macam dan dosis pupuk organik (MD), sedangkan ke 7 tarafnya adalah :

MD0 = Tanpa pupuk (kontrol)

MD1 = Pupuk kandang dosis 200g/polybag MD2 = Pupuk kandang dosis 400g/polybag 
MD3 = Pupuk guano dosis $200 \mathrm{~g} /$ polybag MD4 = Pupuk guano dosis $400 \mathrm{~g} / \mathrm{polybag}$ MD5 = Pupuk kascing dosis $200 \mathrm{~g} /$ polybag MD6 = Pupuk kascing dosis 400 g/polybag

Data dianalsis menggunakan analisis ragam untuk mengetahui pengaruh dari perlakuan tersebut. Pengaruh perlakuan dikatakan nyata apabila nilai F-hitungnya lebih besar dari F-tabel 5\% ; dan dikatakan sangat nyata apabila nilai Fhitungnya lebih besar dari niai F-tabel $1 \%$, sedangakan dikatakan tidak nyata apabila nilai F-hitungnya lebih kecil dari F-tabel 5\% (Gaspersz, 1991 ; Sugandi dan Sugiarto, 1994). Analisis selanjutnya menggunakan Uji Beda Nyata Jujur (BNJ) pada taraf 5\% untuk mengetahui perlakuan-perlakuan yang berpengaruh dan yang tidak berpengaruh (Garspersz, 1991 ; Sungadi dan Sugisrto, 1994 ; Steel dan Torrie, 1989)

\section{HASIL DAN PEMBAHASAN HASIL}

Hasil penelitian (Tabel 1) menunjukkan bahwa perlakuan penerapan macam dan dosis pupuk organik berpengaruh terhadap 3 parameter pertumbuhan, yaitu tinggi tanaman, jumlah daun, dan jumlah anakan; sedangkan terhadap 2 parameter lainnya yaitu berat segar dan berat kering brangkasan tidak berpengaruh.

Tabel 1. Hasil Penelitian Penerapan Macam dan Dosis Pupuk Organik Terhadap Pertumbuhan Tanaman Gandum

\begin{tabular}{lcrrrr}
\hline Perlakuan & \multicolumn{6}{c}{ Parameter Pertumbuhan } \\
\cline { 2 - 6 } & $\begin{array}{c}\text { Tinggi } \\
\text { tanaman } \\
(\mathrm{cm})\end{array}$ & $\begin{array}{c}\text { Jumlah daun } \\
\text { (helai) }\end{array}$ & $\begin{array}{l}\text { Jumlah } \\
\text { anakan } \\
\text { (batang) }\end{array}$ & $\begin{array}{c}\text { Berat Segar } \\
\text { Brangkasan } \\
(\mathrm{g})\end{array}$ & $\begin{array}{c}\text { Berat kering } \\
\text { brangkasan } \\
(\mathrm{g})\end{array}$ \\
\hline MD0 & $60,42 \mathrm{ab}$ & $24,2 \mathrm{ab}$ & $10,4 \mathrm{ab}$ & $14,73 \mathrm{a}$ & $8,48 \mathrm{a}$ \\
MD1 & $61,36 \mathrm{ab}$ & $25,6 \mathrm{ab}$ & $9,0 \mathrm{ab}$ & $10,05 \mathrm{a}$ & $5,48 \mathrm{a}$ \\
MD2 & $64,16 \mathrm{ab}$ & $42,6 \mathrm{~b}$ & $15,6 \mathrm{~b}$ & $16,23 \mathrm{a}$ & $9,91 \mathrm{a}$ \\
MD3 & $66,16 \mathrm{~b}$ & $28,8 \mathrm{ab}$ & $12,2 \mathrm{ab}$ & $13,03 \mathrm{a}$ & $8,39 \mathrm{a}$ \\
MD4 & $55,54 \mathrm{a}$ & $14,4 \mathrm{a}$ & $6,0 \mathrm{a}$ & $7,29 \mathrm{a}$ & $5,00 \mathrm{a}$ \\
MD5 & $68,30 \mathrm{~b}$ & $34,8 \mathrm{~b}$ & $14,4 \mathrm{~b}$ & $19,41 \mathrm{a}$ & $12,73 \mathrm{a}$ \\
MD6 & $64,96 \mathrm{~b}$ & $32,2 \mathrm{ab}$ & $12,4 \mathrm{ab}$ & $15,57 \mathrm{a}$ & $10,01 \mathrm{a}$ \\
\hline
\end{tabular}

Keterangan :

Angka yang diikuti huruf sama pada kolom yang sama berarti tidak berbeda nyata

Hasil penelitian (Tabel 2) perlakuan penerapan macam dan dosis pupuk organik tidak berpengaruh terhadap 3 parameter hasil, yaitu jumlah biji, berat biji, berat 100 biji.

Tabel 2. Hasil Penelitian Penerapan Macam dan Dosis Pupuk Organik Terhadap Hasil Tanaman Gandum

\begin{tabular}{lrrr}
\hline \multirow{2}{*}{ Perlakuan } & \multicolumn{3}{c}{ Parameter Pertumbuhan } \\
\cline { 2 - 4 } & Jumlah biji (butir) & \multicolumn{1}{c}{ Berat biji (g) } & Jumlah anakan (batang) \\
\hline MD0 & $53,4 \mathrm{a}$ & $1,51 \mathrm{a}$ & $28,4 \mathrm{a}$ \\
MD1 & $39,4 \mathrm{a}$ & $1,09 \mathrm{a}$ & $2,76 \mathrm{a}$ \\
MD2 & $53,6 \mathrm{a}$ & $1,85 \mathrm{a}$ & $3,46 \mathrm{a}$ \\
MD3 & $58,2 \mathrm{a}$ & $2,15 \mathrm{a}$ & $3,70 \mathrm{a}$ \\
MD4 & $43,8 \mathrm{a}$ & $1,34 \mathrm{a}$ & $3,05 \mathrm{a}$ \\
MD5 & $92,4 \mathrm{a}$ & $3,38 \mathrm{a}$ & $3,66 \mathrm{a}$ \\
MD6 & $68,0 \mathrm{a}$ & $2,25 \mathrm{a}$ & $3,31 \mathrm{a}$ \\
\hline
\end{tabular}

Keterangan :

Angka yang diikuti huruf sama pada kolom yang sama berarti tidak berbeda nyata 


\section{PEMBAHASAN}

\section{Pengaruh Penerapan Macam dan Dosis Pupuk Organik Terhadap Pertumbuhan Gandum}

Berdasarkan Tabel 1 diketahui bahwa tinggi tanaman, tertinggi yaitu 68,30 $\mathrm{cm}$ diperoleh pada penerapan pupuk kascing dengan dosis 200 g/polybag (MD5), Sedangkan tinggi tanaman terrendah yaitu $55,54 \mathrm{~cm}$ diperoleh pada penerapan pupuk guano dengan dosis $400 \mathrm{~g} /$ polybag (MD4). Tinggi tanaman merupakan hasil pertumbuhan dan perkembangan tanaman. Pertambahan tinggi tanaman merupakan bentuk peningkatan pembelahan sel-sel akibat adanya translokasi asimilat yang meningkat. Tinggi tanaman bukanlah indikator utama pertumbuhan tanaman. Di sisi lain tanaman yang labih tinggi tidak menjamin produktivitas suatu tamana lebih tinggi karena tanaman yang tinggi tetapi batangnya lemah akan rentan terhadap kerebahan.

Rendahnya tinggi tanaman selama pertumbuhan gandum pada perlakuan pemupukan disebabkan karena unsur $\mathrm{N}$ maupun unsur hara lainnya dalam tanah menjadi faktor pembatas. Nitrogen diperlukan untuk pembentukan sel-sel baru. Apabila tanaman mengalami kekurangan $\mathrm{N}$ maka pembelahan sel terhambat, selain itu karbohidrat yang dihasilkan pada proses fotosintesis tidak dapat diubah menjadi protein atau asam-asam nukleat sehingga tanaman tidak dapat melangsungkan proses fisiologi. Nitrogen berpengaruh terhadap laju pembelahan dan pembesaran sel. Menurut Haryadi (1983), jika laju pembelahan dan perpanjangan sel berlangsung dengan cepat maka pertumbuhan batang, akar, maupun daun berjalan dengan cepat pula.

Dosis pemupukan $\mathrm{N}$ perlu mempertimbangkan ketersediaan $\mathrm{N}$ dalam tanah, kandungan bahan organic, dan potensi hasil yang ingin dicapai. Tanah dengan kandungan bahan organik tinggi membutuhkan pemupukan $\mathrm{N}$ lebih sedikit dibanding tanah dengan kandungan bahan organik rendah. Pada tanah dengan kandungan organik $>4 \%$ tanaman gandum membutuhkan 55-80 kg N/ha, pada tanah dengan bahan organik 2-4\% membutuhkan 80-105 kg N/ha, dan bila kandungan bahan organik tanah $<2 \%$ tanaman gandum membutuhkan 105-130 kg N/ha (Shelley, 2014)

Tabel 1 juga menunjukkan bahwa jumlah daun terbanyak yaitu 42,6 helai diperoleh pada perlakuan penerapan pupuk kandang dengan dosis 400 g/polybag tanaman (MD2), sedangkan jumlah daun tersedikit yaitu 14,4 helai diperoleh pada perlakuan penerapan pupuk guano dengan dosis $400 \mathrm{~g} /$ polybag (MD4).

Daun merupakan organ utama tempat fotosintesis dengan hasil fotosistat yang digunakan oleh tanaman dalam pertumbuhan dan perkembangannya. Perkembangan daun-daun baru pada tanaman dipengaruhi oleh pasokan asimilat yang berasal dari daun yang lebih dewasa. Asimilat tersebut digunakan untuk membentuk daun baru dan membesarnya berasal dari hasil fotosintesis daun yang lebih dewasa. Daun-daun dewasa dapat menjalankan fotosintensis dengan baik kalau faktor-faktornya mendukung antara lain ketersediaan nutrisi.

Anakan terbanyak yaitu 15,6 batang diperoleh pada perlakuan penerapan pupuk kandang dengan dosis 400 g/polybag, sedangkan jumlah anakan tersedikit yaitu 6,0 batang diperoleh pada perlakuan penerapan pupuk guano dengan dosis 400 g/polybag (MD2).

Tidak terjadinya peningkatan jumlah anakan secara nyata pada penerapan pupuk guano dengan dosis 400 g/polybag menunjukkan bahwa penerapan pupuk tersebut belum mampu meningkatkan ketersediaan unsur hara sesuai kebutuhan tanaman. Diduga kebutuhan tanaman akan unsur hara baru terpenuhi setelah penerapan pupuk kandang dengan dosis 400 g/polybag yang ditandai dengan peningkatan jumlah anakan secara nyata. Menurut Setyamidjaja (1986) cit Suwarno (2005), pada fase pembentukkan anakan harus tersedia unsur hara nitrogen yang cukup agar dapat merangsang tumbuhnya anakan. Hal ini berarti bahwa ketersediaan unsur hara nitrogen dapat merupakan faktor penghambat munculnya anakan pada tanaman gandum.

Berat segar brangkasan tertinggi yaitu 19,41 g diperoleh pada perlakuan penerapan pupuk kascing dengan dosis 200 g/polybag (MD5) tetapi tidak berbeda jika 
dibandingkan dengan berat segar brangkasan terrendah yaitu $7,29 \mathrm{~g}$ yang diperoleh pada perlakuan penerapan pupuk guano dengan dosis $400 \mathrm{~g} /$ polybag (MD4). Kondisi yang sama juga terjadi pada berat kering brangkasan di mana pada penerapan pupuk kascing dengan dosis $200 \mathrm{~g} /$ polybag (MD5) akan menghasilkan berat kering tertinggi yaitu $12,73 \mathrm{~g}$ tetapi tidak berbeda jika dibandingkan dengan berat kering brangkasan terrendah yaitu $5,00 \mathrm{~g}$ yang diperoleh pada perlakuan penerapan pupuk guano dengan dosis $400 \mathrm{~g} /$ polybag.

Berat brangkasan basah dan brangkasan kering dipengaruhi oleh parameter tinggi tanaman dan parameter jumlah daun karena semakin tinggi tanaman dan semakin banyak jumlah daunnya maka berat segar brangkas juga akan meningkat, dengan semakin banyak jumalh daun maka proses fotosintesis yang menghasilkan fotosintat akan mempengaruhi berat brangkasan basah. Menurut Sitompul dan Guritno (1995), pertambahan ukuran organ tanaman akibat dari pertambahan ukuran sel, jumlah sel atau ruang (volume) sel yang semakin besar akan membutuhkan semakin banyak fotosintat yang disintesis. Apabila didukung dengan peningkatan laju fotosintesis karena kondisi lingkungan yang optimal sehingga menghasilkan lebih banyak fotositat yang akan berpengaruh pada berat tanaman yang ditunjukkan oleh berat brangkasan basah. Meningkatnya unsur hara akan memacu pertumbuhan tanaman dna meningkatkan berat, jumlah organ-organ tanaman (batang, daun, akar) sehingga berat brangkasan basah akan meningkat (Yulita dan Risda, 2006).

\section{Pengaruh Penerapan Macam dan Dosis Pupuk Organik Terhadap Hasil Gandum}

Berdasarkan Tabel 2, diketahui bahwa jumlah biji terbanyak yaitu 92,4 butir diperoleh pada perlakuan penerapan pupuk kascing dengan dosis 200 gram setiap polybag, namun tidak berbeda nyata jika dibandingkan dengan jumlah biji tersedikit yaitu 39,4 butir yang diperoleh pada perlakuan pupuk kandang dengan dosis 200 gram setiap polybag. Hal yang sama juga terjadi pada berat biji di mana berat biji terberat yaitu 3,38 g yang diperoleh pada perlakuan pupuk kascing dengan dosis 200 gram setiap polybag tidak berbeda dengan berat biji teringan yaitu $1,09 \mathrm{~g}$ yang diperoleh pada perlakuan pupuk kandang dengan dosis 200 gram setiap polybag.

Tidak terjadinya peningkatan jumlah dan berat biji, diduga karena dipengaruhi oleh suhu udara yang melebihi batas optimum untuk pertumbuhan tanaman gandum dan kekurangan air yang ditandai dengan permukaan tanah yang retak, hal ini menyebabkan proses pengisian biji kurang optimal sehingga dampaknya pada kualitas biji yang keriput dan kuantitas yang dihasilkan. Hal ini didukung dengan pernyataan Stone (2001), yang menyatakan bahwa pengaruh suhu tinggi terhadap perkembangan bulir pada tanaman serealia meliputi laju perkembangan bulir yang lebih cepat, penurunan berat bulir, biji keriput, berkurangnya laju akumulasi pati serta perubahan komposisi lipid dan polipeptida.

Tabel 2 juga menunjukkan bahwa berat 100 biji tertinggi yaitu $3,70 \mathrm{~g}$ diperoleh pada penerapan pupuk guano dengan dosis $400 \mathrm{~g} /$ polybag tetapi tidak berbeda dibandingkan berat 100 biji terrendah yaitu 2,76 g yang diperoleh pada penerapan pupuk kandang dengan dosis 200 g/polybag.

\section{KESIMPULAN}

Berdasarkan hasil penelitian dan pembahasan maka dapat disimpulkan:

1. Penerapan macam dan dosis pupuk organik berpengaruh terhadap tinggi tanaman, jumlah daun, dan jumlah anakan tanaman gandum.

2. Penerapan macam dan dosis pupuk organik tidak berpengaruh terhadap berat segar brangkasan, berat kering brangkasan, jumlah biji, berat biji, dan berat 100 biji.

3. Macam dan dosis pupuk terbaik adalah MD2 (pupuk kandang dosis 400 g/polybag) karena dapat meningkatkan jumlah daun dan jumlah anakan.

DAFTAR PUSTAKA

Anonim, 2011.Gandum. Dinas Pertanian Tanaman Pangan Kabupaten Pasuruan Jawa Timur. dari http://www.dispertakabpasuruan.com. 
Gaspersz, V., 1991. Teknik Analisis dalam Penelitian Percobaan. Tarsito. Bandung.

Haryadi, S.S 1983. Pengantar Agronomi. Gramedia. Jakarta. 195 hal.

Nur, A., Khumaida, N., Yahya, S. 2012 evaluasi dan Keragaman Genetik 12 Galur Gandum Intriduksi di Lingkungan Tropika Basah. Agrivigor Vol 11. Hal 231-232.

Shelley, K.B. 2014. Nitrogen fertilizer rates and application timing for winter wheat in Wisconsin-What are the economic optimums. Univ. Of Wisconsin- Extension Nutrient and Pest Manangement Program.

Sitompul dan Bambang Guritno. 1995. Analisis Pertumbuhan Tanaman. UGM Press. Yogyakarta. 412 hal

Steel R.G.D. dan J.H. Torrie, 1989. Prinsip dan Prosedur Stasistika : Suatu Pendekatan Biometrik. Terjemahan Bamabang Sumantri (IPB). Jakarta : PT Gramedia, 748 hal.

Stone, P. 2001. The effects of heat stress on cereal yield and quality. In: Basra,
A.S. (Ed.). Crop Responses and Adaptation to Temperature Stress. Food Products Press, Binghamton. New York. Hal 23-31.

Sugandi, E. dan Sugiarto, 1994. Rancangan Percobaan : Teoru dan Aplikasi. Yogyakarta : Andi Offset. 236 hal.

Suwarno, 2005. Pengaruh Pengapuran Terhadap Hasil Gandum (Triticum aestivum L.) yang Ditumpangsari dengan Bawang Daun (Allium fitsulosum L.). Skripsi. Fakultas Pertanian Universitas Slamet Riyadi Surakarta.

Suwarno dan K. Idris. 2007. Potensi Dan Kemungkinan Penggunaan Guano Secara Langsung Sebagai Pupuk Di Indonesia. Jurnal Tanah dan lingkungan Vol. 9 No. 1.

Yulita dan Risda. 2006. Berbagai Produk Pangan Berbasis Sorgum. Workshop Sorgum Developmentin Indonesia. Biotrop. Bogor 